\title{
Susan Greenhalgh, Just One Child: Science and Policy in Deng's China
}

Berkeley, UC Press, 2008, 404 pp.

Ellen R. Judd

\section{OpenEdition}

\section{Journals}

Electronic version

URL: http://journals.openedition.org/chinaperspectives/4824

DOI: $10.4000 /$ chinaperspectives.4824

ISSN: 1996-4617

\section{Publisher}

Centre d'étude français sur la Chine contemporaine

Printed version

Date of publication: 1 June 2009

Number of pages: $124-125$

ISSN: 2070-3449

\section{Electronic reference}

Ellen R. Judd, « Susan Greenhalgh, Just One Child: Science and Policy in Deng's China », China Perspectives [Online], 2009/2 | 2009, Online since 01 June 2009, connection on 21 September 2020. URL : http://journals.openedition.org/chinaperspectives/4824 ; DOI : https://doi.org/10.4000/ chinaperspectives. 4824

This text was automatically generated on 21 September 2020.

(c) All rights reserved 


\section{Susan Greenhalgh, Just One Child: Science and Policy in Deng's China}

Berkeley, UC Press, 2008, 404 pp.

Ellen R. Judd

1 Readers in the China field will eagerly turn to Susan Greenhalgh's latest work for an indepth treatment of the formation of China's one-child policy, but they will find much more here. This volume exemplifies some of the strongest work in the anthropology of China in the present day, pulling ethnographic research in China into the mainstream of central debates in contemporary anthropology.

2 Greenhalgh makes two broad types of knowledge claim in this volume, both based on diverse ethnographic techniques. First, she claims to explain, in considerable ethnographic and analytic depth, the specific policy-making process through which China arrived at the one-child-percouple formulation during critical months in 197980. This is a significant addition to the comprehensive work she co-authored with Edwin Winckler, Governing China's Population: From Leninist to Neoliberal Biopolitics (Berkeley, University of California Press, 2005). In the present work she examines three competing scientific groups and their positions, as well as the political and scientific means through which the contention unfolded. These comprised the population studies group at People's University, led by Liu Zheng and others; the cybernetic missile control scientists led by Song Jian; and the critical voice of Liang Zhongtang of the Shanxi Party School.

3 The population studies group was severely hampered by an immediate lack of population data and computing facilities, as well as a deeper disadvantage derived from the devaluing and dismantling of the social sciences in previous decades. Liang Zhongtang suffered comparable disadvantages, which even his strong political legitimacy and roots in popular society and culture were unable to overcome. The ultimate decision was made in favour of the missile scientists' argument that the population problem was biological rather than social in nature, and that this prob lem was both absolutely urgent and effectively controllable by means similar to those used to create a missile capability for China. The privileged access of the missile control 
scientists to data, computers, international conferences, and the ears of the highest leadership in China are all traced, as is their deployment of political and discursive strategies.

4 Second, Greenhalgh argues for what she describes as an epistemic or knowledge-based approach to an anthropology of policy.

5 She departs from the threshold call of Laura Nader to "study up" by pursuing a study of China's population policy that models the approach of problematising what is thinkable. She is strongly informed here by work in STS (science and technology studies), and uses insights derived largely from work on laboratory science to illuminate the science of "population" and the relation between science and policy. Greenhalgh had extraordinary ethnographic and interview access, gained initially through her ten years with the Population Council. Her long-term personal knowledge of many of the principal figures and her interview access to them for this study are essential for the exceptional task of analysing the elite processes that culminated in the one-child policy decision in 1980. It is perhaps her key argument that contention about science and the interface between science and policy was decisive in the making of this policy. This underlies all of the complex argumentation about how the policy was made, which she presents with carefully delineated and cited evidence (while protecting confidentiality, where necessary) and judicious and probabilistic language. This is probably the element of the book most subject to debate, as the official position is that the decision was a political one made by the top political leaders, with science being a subsidiary matter.

6 The exact process of decision-making by the handful of top leaders (Chen Yun, Li Xiannian, Deng Xiaoping, Chen Muhua, and a few others) may be contingent and ultimately unknowable with absolute certainty, but readers will do well to follow Greenhalgh through these perilous waters. The voyage leads through problematisations of science, the power of visualisation in diagrams and charts, the magic of numbers (even when based on doubtful sources), the role of simplification (of complex processes) and factification, and the importance of linguistic framings. She also takes us through the mechanisms of elite science policy-its boundary work (and boundary violations), publication strategies, oratory and management of resources and connections.

7 A recurrent and culminating argument is the descent of science into scientism and the perils this holds in a world uncritically enamoured of the trappings and questionable legitimacy of ready scientific (scientistic) explanations and solutions. Lest one imagine that this is unique or special to China, Greenhalgh shows that the one-child policyoften attributed solely to China-had roots in missile scientists' exposure to and import of Club of Rome population concepts through international conferences in the 1970s. A peculiar feature of the context was the exceptional faith China's leaders placed in Western science, which contributed to the scientism that legitimated the onechild policy. Similarly, the political lines are shown to be at odds with stereotypical interpretations of Chinese politics. The decisive proponents of the view of population as a matter of biology and its quantitative control were an integral segment of China's new elite, and while politically well-connected, they had been somewhat removed and protected from ordinary political involvement or rustication due to their contributions to China's missile control technology. The specialists at People's University had political vulnerabilities associated with earlier political campaigns and a lower status as 
social scientists that hampered their ability to speak out. The spokesperson closest to revolutionary political culture, Liang Zhongtang, described by Greenhalgh as a Marxist humanist, was the one who paid the greatest attention to the social impact of the onechild policy, especially for the elderly (but less so for women), and was able to urge a more socially responsive and gradual approach. Greenhalgh's study is grounded in an in-depth case study of this turning point in China's most important policy of the late twentieth century, but it is also a work of ethnology with wider applicability. She delineates how momentous scientific authority can be fragile and contingent, how it requires identifiable practices to make it powerful, and how it resides in the everyday discourses of science and politics. Elite science policy is not the usual haunt of anthropologists, but Greenhalgh and charts, the magic of numbers (even when based on doubtful sources), the role of simplification (of complex processes) and factification, and the importance of linguistic framings. She also takes us through the mechanisms of elite science policy-its boundary work (and boundary violations), publication strategies, oratory and management of resources and connections. A recurrent and culminating argument is the descent of science into scientism and the perils this holds in a world uncritically enamoured of the trappings and questionable legitimacy of ready scientific (scientistic) explanations and solutions. Lest one imagine that this is unique or special to China, Greenhalgh shows that the one-child policy- often attributed solely to China-had roots in missile scientists' exposure to and import of Club of Rome population concepts through international conferences in the 1970s. A peculiar feature of the context was the exceptional faith China's leaders placed in Western science, which contributed to the scientism that legitimated the onechild policy.

8 Similarly, the political lines are shown to be at odds with stereotypical interpretations of Chinese politics. The decisive proponents of the view of population as a matter of biology and its quantitative control were an integral segment of China's new elite, and while politically well-connected, they had been somewhat removed and protected from ordinary political involvement or rustication due to their contributions to China's missile control technology. The specialists at People's University had political vulnerabilities associated with earlier political campaigns and a lower status as social scientists that hampered their ability to speak out. The spokesperson closest to revolutionary political culture, Liang Zhongtang, described by Greenhalgh as a Marxist humanist, was the one who paid the greatest attention to the social impact of the onechild policy, especially for the elderly (but less so for women), and was able to urge a more socially responsive and gradual approach.

9 Greenhalgh's study is grounded in an in-depth case study of this turning point in China's most important policy of the late twentieth century, but it is also a work of ethnology with wider applicability. She delineates how momentous scientific authority can be fragile and contingent, how it requires identifiable practices to make it powerful, and how it resides in the everyday discourses of science and politics. Elite science policy is not the usual haunt of anthropologists, but Greenhalgh aptly frames this as another instance of the "ethnography in strange places" (p. 312) that is what anthropologists do. We can be grateful that she has pushed these boundaries and done so with such rigour and insight. 


\section{AUTHOR}

ELLEN R. JUDD

Professor in the Department of Anthropology, University of Manitoba, Canada. 